UDC 613.292 : (612.395 + 612.395.6) (082)

\title{
EFFECT OF SUCRALOSE ON THE BLOOD CONTENT OF THYROID HORMONES
}

\author{
O. OLIYNYK ${ }^{1,2 \bowtie}$, A. SLIFIRCZYK 1 , Y. OLIYNYK ${ }^{3}$, B. PEREVIZNYK ${ }^{3}$ \\ ${ }^{1}$ Pope John Paul II State School of Higher Education, Biała Podlaska, Poland; \\ ${ }^{2}$ Bogomolets National Medical University, Kyiv, Ukraine; \\ ${ }^{3}$ I. Horbachevsky Ternopil National Medical University, Ukraine; \\ e-mail: Alexanderoliynyk8@gmail.com
}

Received: 22 February 2020; Accepted: 25 June 2020

\begin{abstract}
Sugar substitutes are among the most widely used food additives. Increasing number of scientific research on their adverse effect on various body functions has been appearing lately. The objective of this research is to study the effect of sucralose, a sugar substitute, on the thyroid functional state. Involved in the research were 30 women, aged 19-28, estimating themselves healthy. The blood content of free and general triiodothyronine, free and general thyroxine, as well as of thyrotropic hormone were determined. Thereafter, the women were taking sucralose for a month daily in a dose of $15 \mathrm{mg} / \mathrm{kg}$, the blood content of the hormones mentioned above having been tested again. Reliable 2.0, 1.58, and 1.46 times decrease in the blood content of free and general triiodothyronine, and general thyroxine, respectively, as well as reliable 4.41 times increase in the blood content of thyrotropic hormone $(P<0.001)$ were found. Our findings on the sucralose-induced decrease in the level of thyroid hormones confirmed the results of other researchers regarding sucralose as biologically inert compound that should be kept in mind when evaluating its effect on the patients with endocrine pathology.
\end{abstract}

Ke ywords: thyroid hormones, sucralose introduction.

$\mathrm{T}$ hyroid hormones are essential for normal functioning of many organs and body systems. Thyroid function is controlled by dynamic interrelations between hypothalamus, pituitary gland, and thyroid. This interaction is realized due to tissue mechanisms including metabolism and thyroid hormones transport. There are some environmental chemical substances, capable of suppressing thyroid function (Endocrine Disrupting Chemicals, EDC) by adversely affecting hormone production. These substances are called thyroid toxicants and include a wide range of chemical structures, acting through various mechanisms. Many environmental pollutants act as toxicants. Therefore, they are also called thyroid destroying agents. In the broad sense, these substances change regulatory enzymes, involved in thyroid hormones homeostasis. Recently, the issue of thyroid toxicants has been drawing considerable attention. There is an increasing number of experimental evidence, proving that some substances are thyroid toxicants. However, extrapolation of animal experimental findings on the humans is restrained by uncertain mechanisms of toxicants' action, which may differ in various species. The substances routinely used as food additives, sweeteners in particular, have been found to possess toxicant characteristics [1]. Their effect on the human metabolism has not been studied thoroughly so far. Previously, the influence of some food sweeteners on thyroid hormones activity was studied experimentally only. The objective of this research is to study the effect of sucralose, a widely used sugar substitute, on the thyroid functional state.

\section{Materials and Methods}

Involved in the research were 30 Polish women, aged 19-28, residents of Lublin province, Biala Podlaska district, estimating themselves healthy. The

(C) 2020 Oliynyk O. et al. This is an open-access article distributed under the terms of the Creative Commons Attribution License, which permits unrestricted use, distribution, and reproduction in any medium, provided the original author and source are credited. 
blood content of free (FT3) and general (T3) triiodothyronine, free (FT4) and general (T4) thyroxine, as well as of thyrotropic hormone (TSH) was determined [2]. Thereafter, the women were taking StarkPharm sucralose for a month daily in a dose of $15 \mathrm{mg} / \mathrm{kg}$ that is regarded as maximum allowable according to EDQM (European Directorate for the Quality of Medicines\&Health Care) recommendations [3]. When dosing sucralose powder, it was assumed that $1 \mathrm{~cm}^{3}$ contains $350 \mathrm{mg}$ of sucralose. In a month, the blood content of all the hormones mentioned was tested again. Statistical processing included calculation of mean arithmetic values (M) and standard deviation (SD). The data array was tested for normal distribution using the Shapiro-Wilk test. Source data having normal distribution, Student $t$-distribution was used to determine statistical significance of different mean values. The levels of statistical significance were calculated, the changes regarded as significant at $P<0.001$. Microsoft Excel 2010 and StatsoftSTATISTICA 10 programs were used for calculations. The research was financed from the grant of Pope John Paul II State School of Higher Education, Biala Podlaska and approved by the Bioethics committee of the school mentioned.

\section{Results and Discussion}

We have noted reliable 2.0, 1.58 and 1.46 times $(P<0.001)$ decrease in the blood content of FT3, T3 and T4, respectively, at the background of sucralose intake in comparison with the values prior to the use of sucralose. After taking sucralose, THS blood content was reliably 4.41 times $(P<0.001)$ the value prior to sucralose use. Though changed reliably, the studied thyroid hormones and TSH were found to be within the limits of their normal

Blood content of thyroid hormones in the women examined prior to and after sucralose intake

\begin{tabular}{l|c|c}
\hline \multicolumn{1}{c|}{ Index } & $\begin{array}{c}\text { Baseline } \\
(n=30)\end{array}$ & $\begin{array}{c}\text { After sucralose } \\
\text { intake }(n=30)\end{array}$ \\
\hline TSH, mlU/l & $1.25 \pm 0.50$ & $5.52 \pm 2.77^{*}$ \\
FT3, pg/ml & $3.16 \pm 0.40$ & $1.56 \pm 0.35^{*}$ \\
FT4, ng/dl & $1.10 \pm 0.19$ & $0.81 \pm 0.22$ \\
T3, ng/dl & $101.54 \pm 13.96$ & $64.45 \pm 8.47^{*}$ \\
T4, ng/dl & $7.47 \pm 1.28$ & $5.13 \pm 0.65^{*}$ \\
\hline
\end{tabular}

Footnote: *reliable difference of results as compared with those in the group of women with normal thyroid function $(P<0.001)$. content. Therefore, despite reliable decrease in the thyroid hormones content, the state of the thyroid after taking sucralose can not be characterized as subclinical hypothyroidism (Table). The symptoms of impaired thyroid functional state in the women under examination after taking sucralose have not been found either.

During discussion of results, it is worth recalling that impaired thyroid function is among the most common human pathologies, its prevalence varying regionally and primarily depending on the iodine intake. Impairment of thyroid function is divided into manifest and subclinical forms [4]. Manifest forms are characterized by changing levels of both TSH and thyroid hormones, while subclinical forms reveal changed TSH only with the level of thyroid hormones remaining normal. Manifest hypothyroidism has been found to cause numerous abnormalities in various organs and systems: enhanced fatigability, oedemas, constipation, cognitive disturbances, menstrual disorders, paresthesia, bradycardia, dyslipidaemia, etc. Subclinical hypothyroidism can reveal itself in numerous and nonspecific symptoms, similar to those in manifest hypothyroidism, though lack of any symptoms may also occur. Subclinical hypothyroidism is an independent risk factor for atherosclerosis and myocardial infarction [4]. Subclinical thyroid abnormalities are more prevalent than manifest ones. Functional thyroid disorders are more frequent in the areas with inadequate iodine intake with food. It is noteworthy that Biala Podlaska, the site of research, is endemic in terms of iodine, manifest hypothyroidism being found in $0.2-2 \%$ of the population and subclinical one - in 8-10\% [5]. Prevalence of hyperthyroidism increases with age and is higher in Caucasians than in the people of other races. High risk group of thyroid abnormalities development includes postpartum women and the elderly.

Intake of toxicants may lead to various disorders in the thyroid functional state. Endocrine abnormalities owing to thyroid toxicants effect are commonly associated with a wide range of adverse consequences. Prototype thyroid toxicants, such as dioxines, polychlorinated diphenyls, and polybrominated diphenyl ethers have been proven to change thyroid hormones homeostasis, mainly by activating their hepatic catabolism [6-8].

Our findings confirm the results by PalkowskaGozdzik E. et. al., 2016, who studied thyroid functional state in albino rats after three-week sucralose 
intake. The authors have found the sucralose intake changing thyroid peroxidase activity and declining thyroid hormones synthesis [9]. The change of thyroid hormones peripheral metabolism has been suggested as a possible cause. It was concluded that sucralose is metabolically active and capable of aggravating metabolic disorders through adversely affecting thyroid hormones metabolism.

These data alongside with our findings upset the existing perception of absolute sucralose harmlessness. Sucralose (chemical name - trichloro galacto saccharose), molecular formula $\mathrm{C}_{12} \mathrm{H}_{19} \mathrm{Cl}_{3} \mathrm{O}_{8}$, is a low calorie sweetener, used in a wide range of foodstuffs and drinks. As a universal sweetener, sucralose was approved by FDA (US Food and Drug Administration) in 1999 and by EFSA (European Food Safety Authority) in 2004. In addition, recommendation that sucralose should be used as additive was approved by EDQM (European Directorate for the Quality of Medicines \&Health Care) on July 2, 2010[10]. Until a few years ago, the sweetener was regarded as absolutely safe. However, in a few recent years perception of sucralose as absolutely nontoxic has somewhat changed.

Sucralose intake by rats has been shown to increase expression of P-glycoprotein (P-gp) efflux transporter and of two cytochrome P450 isoenzymes(CYP) in the intestine [11]. P-gp and CYP are the key components of presystemic detoxification, involved in drug metabolism. Sucralose has been proven to change microbial composition in the gastrointestinal tract (GIT), significant decrease in the amount of useful bacteria included. Although early research asserted that sucralose passes through GIT unchanged, the follow-up study has revealed that a portion of sweetener taken is metabolized in the GIT, as evidenced by numerous peaks found in thin-layer radiochromatographic profiles of faecal methanol extracts after peroral sucralose intake [11]. At present, identity and safety profile of supposed sucralose metabolites is unknown.

Sucralose intake has been found to change intestinal microbiome [12], the latter playing a key role in the processes, essential for the host health, such as gastrointestinal digestion and fermentation, development of immune cells and regulation of intestinal nervous system. Inflammation is a common consequences of intestinal microbiome dysbiosis. Bian X. et al., 2017 [13] studied structural and functional sucralose effect on the intestinal microbiote and associated inflammation in the host. In this re- search, males of C57BL/6 mice were being given sucralose with drinking water for 6 months. Difference in the composition of intestinal microbiote and metabolites in control mice and those, which were given sucralose, was determined using squamation of $16 \mathrm{~S}$ pRNA genes, analysis of gene functional enrichment, and metabolomics. Expression of inflammation genes in the tissues of the intestine was analysed. According to research findings, sucralose affects intestinal microbiote and dynamics of its changes. Enrichment of bacterial pro-inflammatory genes and abnormalities of faecal metabolites would suggest that 6 -month sucralose intake daily $(15 \mathrm{mg} /$ $\mathrm{kg}$ ) is fraught with the risk of tissue inflammation by disordering intestinal microbiote that is accompanied by enhanced pro-inflammatory action. Our findings emphasize the role of sucralose interacting with intestinal microbiome in the regulation of the processes related to the host's health, chronic inflammation in particular.

Besides, sucralose and a product of its hydrolysis have been found in a few test methods to be mutagenic in increased concentrations [14]. Human and rodent studies have shown that sucralose can change the level of glucose, insulin, and glucagon-like peptide 1 (GLP-1) [15].

It can be assumed that accelerated excretion of hormones and bile due to increased sucralose cytochrome P450 activity, reported earlier by Crofton K.M. et al., 2005 [8] may be a possible mechanism of our finding, namely sucralose-induced decreased blood content of thyroid hormones.

Thus, our findings concerning reduced thyroid hormones' level due to sucralose intake agree with the data of other researchers in view of sucralose not being biologically inert that should be particularly kept in mind when estimating its effect on the organism of patients with endocrine pathology.

Conclusion. Daily intake of sucralose for a month provides $2.0,1.58$, and 1.46 times reliable decrease in the blood content of free and general triiodothyronine, and of general thyroxine, respectively, and 4.41 times reliable increase in the blood content of thyrotropic hormone $(P<0.001)$ in the women aged 19-28.

Conflict of interest. Authors have completed the Unified Conflicts of Interest form at http://ukrbiochemjournal.org/wp-content/uploads/2018/12/ coi_disclosure.pdf and declare no conflict of interest. 
Funding. The work was carried out by the expense of the Grant № S / 14/2017 from the Pope John Paul II Higher State School in Biala Podlaska, Poland.

\section{ВПЛИВ СУКРАЛОЗИ НА ВМІСТ ГОРМОНІВ ЩИТОПОДІБНОЇ ЗАЛОЗИ}

\section{О. Олійник ${ }^{1,2 \bowtie}$, А. Сліфірчик ${ }^{1}$ Ю. Олійник ${ }^{3}$,} Б. Перевізник

${ }^{1}$ Вища державна школа імені Папи Яна Павла II в Бялій Підлясці, Польща;

${ }^{2}$ Київський національний медичний університет імені О. О. Богомольця, Україна;

${ }^{3}$ Тернопільський національний медичний університет імені І. Я. Горбачевського, Україна; 凶e-mail: Alexanderoliynyk8@gmail.com

Замінники цукру є одними 3 найчастіше вживаних харчових добавок. Останнім часом з'являється все більше наукових досліджень щодо їх несприятливого впливу на різні функції організму. Метою цього дослідження було вивчення впливу сукралози, замінника цукру, на функціональний стан щитоподібної залози. У дослідженні взяли участь 30 жінок віком 19-28 років, які вважали себе здоровими. Визначали вміст у крові вільного та загального трийодтироніну, вільного та загального тироксину, а також тиреотропного гормону. Після цього жінки приймали сукралозу протягом місяця щодня у дозі 15 мг/кг, потім вміст гормонів знову перевірявся. Виявлено вірогідне зниження вмісту в сироватці крові вільного та загального трийодтироніну та загального тироксину у $2,0,1,58$ та 1,46 раза відповідно, а також вірогідне збільшення вмісту тиреотропного гормону $(P<0,001)$. Одержані дані про зниження під впливом сукралози рівня гормонів щитоподібної залози підтверджують висновки інших дослідників про те, що сукралоза $є$ біологічно активною сполукою, про що слід пам'ятати, оцінюючи її вплив на стан пацієнтів з ендокринною патологією.

К л ю ч о в і с л о в а: гормони щитоподібної залози, сукралоза.

\section{References}

1. Vamanu E, Pelinescu D, Gatea F, Sârbu I. Altered in vitro metabolomic response of the human microbiota to sweeteners. Genes (Basel). 2019; 10(7): 535.
2. Sapin R, Schlienger JL. Thyroxine (T4) and triiodothyronine (T3) determinations: techniques and value in the assessment of thyroid function. Ann Biol Clin (Paris). 2003; 61(4): 411-420.

3. European Pharmacopoeia Supplement 10.1. European pharmacopoeia monograph. 2019. Strasbourg, France.Y0001344.

4. Hypothyroidism. National Institute of Diabetes and Digestive and Kidney Diseases. March 2013. Retrieved 5 March 2016.

5. Udovcic M, Pena RH, Patham B, Tabatabai L, Kansara A. Hypothyroidism and the heart. Methodist Debakey Cardiovasc J. 2017; 13(2): 55-59.

6. Zoeller TR. Environmental chemicals targeting thyroid. Hormones (Athens). 2010; 9(1): 28-40.

7. Crofton KM. Thyroid disrupting chemicals: mechanisms and mixtures. Int J Androl. 2008; 31(2): 209-223.

8. Crofton KM, Craft ES, Hedge JM, Gennings C, Simmons JE, Carchman RA, Carter WH Jr, DeVito MJ. Thyroid-hormone-disrupting chemicals: evidence for dose-dependent additivity or synergism. Environ Health Perspect. 2005; 113(11): 1549-1554.

9. Pałkowska-Goździk E, Bigos A, RosołowskaHuszcz D. Type of sweet flavour carrier affects thyroid axis activity in male rats. Eur $J$ Nutr. 2018; 57(2): 773-782.

10. Ford HE, Peters V, Martin NM, Sleeth ML, Ghatei MA, Frost GS, Bloom SR. Effects of oral ingestion of sucralose on gut hormone response and appetite in healthy normal-weight subjects. Eur J Clin Nutr. 2011; 65(4): 508-513.

11. Schiffman SS, Rother KI. Sucralose, a synthetic organochlorine sweetener: overview of biological issues. $J$ Toxicol Environ Health $B$ Crit Rev. 2013; 16(7): 399-451.

12. Rosales-Gómez CA, Martínez-Carrillo BE, Reséndiz-Albor AA, Ramírez-Durán N, ValdésRamos R, Mondragón-Velásquez T, EscotoHerrera JA. Chronic Consumption of Sweeteners and Its Effect on Glycaemia, Cytokines, Hormones, and Lymphocytes of GALT in CD1 Mice. Biomed Res Int. 2018; 2018: 1345282.

13. Bian X, Chi L, Gao B, Tu P, Ru H, Lu K. Gut microbiome response to sucralose and its potential role in inducing liver inflammation in mice. Front Physiol. 2017;8:487.

14. Wong H, Lehman-McKeeman LD, Grubb MF, Grossman SJ, Bhaskaran VM, Solon EG, 
Shen HSL, Gerson RJ, Car BD, Zhao B, Gemzik B. Increased hepatobiliary clearance of unconjugated thyroxine determines DMP 904-induced alterations in thyroid hormone homeostasis in rats. Toxicol Sci. 2005; 84(2): 232-242.

15. Gómez-Arauz AY, Bueno-Hernández N, Palomera LF, Alcántara-Suárez R, De León K,
Méndez-García LA, Carrero-Aguirre M, Manjarrez-Reyna AN, Martínez-Reyes CP, Esquivel-Velázquez M, Ruiz-Barranco A, Baltazar-López N, Islas-Andrade S, Escobedo G, Meléndez G. A Single $48 \mathrm{mg}$ sucralose sip unbalances monocyte subpopulations and stimulates insulin secretion in healthy young adults. J Immunol Res. 2019; 2019: 6105059. 